\title{
Hubungan Pengetahuan Remaja Tentang Kesehatan Reproduksi Dengan Tingkat Kecemasan Pada Remaja Di Desa Pandean Kabupaten Sukoharjo Tahun 2017
}

\author{
Relationship Of Youth Knowledge About Reproductive \\ Health With Youth Anxiety Levels In The Village Of \\ Pandean, Sukoharjo District, 2017
}

\author{
Binuko Amarseto ${ }^{1}$, Lilik Ariyanti² \\ physio.binukoamarseto@stikesnas.ac.id \\ ${ }^{12}$ Program Studi DIV Fisioterapi, STIKES Nasional, Surakarta
}

\begin{abstract}
Abstrak
Kesehatan reproduksi adalah kesejahteraan fisik, mental dan sosial yang utuh dan bukan hanya tidak adanya penyakit atau kelemahan, dalam segala hal yang berhubungan dengan sistem reproduksi dan fungsi-fungsinya serta proses-prosesnya. Pengetahuan tentang kesehatan reproduksi ini tentu saja sangat penting kaitannya dengan perkembangan kehidupan psikologis remaja yang dalam hal ini mulai sering berhubungan dengan hal-hal yang terkait dengan masalah reproduksi, dalam hal ini tentu saja soal seksualitas dan orientasinya yang nantinya akan berakibat terhadap kepercayaan diri dan kecemasan diri. Penelitian ini bertujuan untuk mengetahui hubungan pengetahuan remaja tentang kesehatan reproduksi dengan tingkat kecemasan pada remaja di desa Pandean Kabupaten Sukoharjo 2017. Penelitian ini adalah explanatory research dengan desain cross sectional. Pengumpulan data dilakukan dengan menggunakan kuisioner. Sampel penelitian yaitu remaja yang berjumlah 45 orang dari populasi 81 orang dengan menggunakan teknik simple random sampling. Analisis data menggunakan uji Pearson Product Moment dengan taraf signifikansi $5 \%$. Variabel terikat dalam penelitian ini adalah kecemasan remaja, sedangkan variabel bebas dalam penelitian ini adalah pengetahuan remaja tentang kesehatan reproduksi. Hasil penelitian ini mendapatkan sampel berjumlah 45 orang remaja di desa Pandean, dengan jumlah jenis kelamin terbanyak adalah laki-laki dengan jumlah 30 responden $(66,7 \%)$, mayoritas responden masih bersekolah dan menempuh pendidikan SMA (69\%). Untuk hasil deskripsi data penelitian, rata-rata nilai pengetahuan adalah 15,16 sedangkan nilai rata-rata kecemasan adalah 105,69. Hasil uji data dengan menggunakan Pearson Product Moment mendapatkan hasil nilai $p=0,007$ ( $p<0,05)$ yang berarti hubungan pengetahuan remaja tentang kesehatan reproduksi dengan tingkat kecemasan pada remaja di Desa Pandean Kabupaten Sukoharjo, dengan nilai interval koefisiensi 0,396 yang berarti hubungan pengetahuan remaja tentang kesehatan reproduksi dengan kecemasan memiliki kekuatan hubungan yang rendah yang berarti bahwa meskipun pengetahuan kesehatan reproduksi memiliki korelasi yang signifikan tetapi tidak menjadi pencetus utama tentang kecemasan terhadap remaja.
\end{abstract}

Kata kunci : Kesehatan Reproduksi, Kecemasan, Remaja 


\begin{abstract}
Reproductive health is a complete physical, mental and social welfare and not only the absence of a disease or weakness, in all matters relating to the reproductive system and its functions and processes. Knowledge about reproductive health is of course very important in relation to the development of the psychological life of adolescents who in this case often begin to deal with matters related to reproductive problems, in this case of course the matter of sexuality and orientation which will later result in self-confidence and anxiety self. This study aims to determine the relationship of adolescent knowledge about reproductive health to the level of anxiety in adolescents in the village of Pandean, Sukoharjo District 2017. This research is explanatory research with cross sectional design. Data collection is done by using questionnaires. The research sample was teenagers totaling 45 people from a population of 81 people using simple random sampling technique. Data analysis using Pearson Product Moment test with a significance level of $5 \%$. The dependent variable in this study is adolescent anxiety, while the independent variable in this study is adolescent knowledge about reproductive health. The results of this study obtained a sample of 45 adolescents in Pandean village, with the highest number of sexes being men with 30 respondents $(66.7 \%)$, the majority of respondents still attending school and taking high school education (69\%). For the results of the research data description, the average value of knowledge is 15.16 while the average value of anxiety is 105.69 . The results of the test data using Pearson Product Moment get the results of $p=0.007$ ( $p$ $<0.05)$ which means the relationship of adolescent knowledge about reproductive health with the level of anxiety in adolescents in Pandean Village, Sukoharjo Regency, with a coefficient of 0.396 which means the relationship of adolescent knowledge about reproductive health with anxiety has a low relationship strength.
\end{abstract}

Keywords: Reproductive Health, Anxiety, Youth

\section{Pendahuluan}

Masa remaja juga merupakan masa yang sangat penting dalam perkembangan seseorang. Pada umumnya remaja didefinisikan sebagai masa peralihan dari masa kanak-kanak ke masa dewasa. Peralihan masa kanak-kanak menjadi dewasa melibatkan perubahan berbagai aspek seperti biologis, psikologis, dan sosial budaya Masa remaja adalah salah satu dari fase periode perkembangan manusia. Dalam pertumbuhan dan perkembangan manusia dewasa mengalami suatu tahap yang disebut masa pubertas Seiring dengan perkembangan biologis, maka pada usia tertentu seseorang akan mencapai tahapan kematangan organorgan seks (Sarwono, 2011).

Masa pubertas adalah masa dimana remaja akan mulai tertarik untuk memahami tentang organ reproduksi mereka, baik sekunder maupun primer. Reproduksi sendiri adalah salah satu aspek penting dalam kehidupan manusia. Reproduksi berkaitan dengan kemampuan makhluk hidup beregenerasi, khususnya proses melahirkan keturunan yang terjadi pada manusia (World Health Organization, 2010).

Untuk itu masa-masa remaja adalah masa dimana pengetahuan tentang kesehatan reproduksi menjadi keilmuan yang wajib dimiliki oleh para remaja, mengetahui tentang kesehatan reproduksi tentu saja akan menjadikan remaja lebih mengerti dan tahu cara bersikap tentang bagaimana cara berperilaku terkait dengan organ seks mereka. Kesehatan reproduksi adalah keadaan sejahtera fisik, mental dan social secara utuh, yang tidak semata-mata bebas dari penyakit atau kecacatan dalam semua hal yang berkaitan dengan system reproduksi, fungsi serta prosesnya (Depkes RI, 2001). 
Berbicara tentang kesehatan reproduksi bukan hanya tentang hak laki-laki dan perempuan untuk memperoleh informasi tentang kesehatan seksualnya saja, tetapi juga tentang hal-hal yang berkaitan dengan hukum sehingga remaja tidak mengalami perasaan cemas jika bersentuhan dengan hal-hal yang berkaitan dengan permasalahan seksual. Salah satu faktor yang menyebabkan kecemasan pada remaja pubertas menurut Kanari dkk (2011) adalah karena kurangnya pengetahuan tentang kesehatan reproduksi. Kurangnya pengetahuan karena kurangnya informasi baik dari remaja maupun orang tua, adanya hambatan sopan santun dan rasa malu Dapat pula karena kesenjangan yang sering berkembang antara anak usia pubertas dan orang tua yang menghalangi anak untuk bertanya mengenai perubahan pada tubuhnya. Menurut WHO (2010) masalah kesehatan reproduksi selain ditinjau dari pendekatan siklus kehidupan keluarga yang meliputi beberapa bentuk faktor, ternyata masalah kesehatan reproduksi mencakup area yang jauh lebih luas, dimana masalah tersebut dapat kita kelompokkan sebagai masalah reproduksi, masalah gender dan seksualitas, masalah kekerasan dn perkosaan terhadap perempuan, masalah penyakit yang ditularkan melalui hubungan seksual, masalah pelacuran, dan masalah sekitar teknologi. Kecemasan sendiri bukan merupakan suatu penyakit melainkan suatu gejala. Hal ini akan semakin parah apabila pengetahuan remaja mengenai permasalahan kesehatan reproduksi yang ternyata sedemikain kompleks ini sangat kurang dan pendidikan dari orang tua yang kurang (Proverawati \& Misaroh, 2009).

Berdasarkan uraian di atas peneliti tertarik untuk meneliti tentang hubungan pengetahuan remaja tentang kesejatan reproduksi dengan tingkat kecemasan pada remaja di desa Pandean Kabupaten Sukoharjo, dengan penelitian ini nantinya diharapkan dapat memberikan informasi terkait pentingnya pengetahuan kesehatan reproduksi dengan permasalahan psikologis pada remaja dalam hal ini kecemasan.

\section{Metode Penelitian}

Penelitian ini menggunakan rancangan penelitian deskriptif observasional karena peneliti tidak memberikan perlakuan pada responden, sedangkan pendekatan yang dilakukan untuk penelitian ini adalah dengan menggunakan pendekatan cross sectional.

\section{Subjek penelitian}

Penelitian ini dilaksanakan di Desa Pandean pada bulan Oktober 2017 dengan sampel penelitian berdasarkan rumus perhitungan mendapatkan sampel dengan jumlah 45 orang responden. Sampel dalam penelitian ini adalah remaja karang taruna desa Pandean.

\section{Instrumen Penelitian}

Form pengambilan data, digunakan untuk mengumpulkan data-data yang diambil dari hasil penyebaran quisioner yang diberikan kepada responden. Selain itu juga diberikan quisioner untuk pengambilan data karakteristik responden.

\section{Jalannya Penelitian}

Peneliti mengambil sampel penelitian berdasarkan rumus yang dipakai kemudian memberikan quisioner tentang pengetahuan tentang kesehatan reproduksi dan quisioner tentang kecemasan yang menggunakan ukuran kepercayaan diri. Setelah itu kemudian data-data yang diperoleh dianalisa untuk mendapatkan hasil statistiknya.

\section{Analisa Data}

Mengalisis hubungan antara pengetahuan kesehatan reproduksi dengan kecemasan pada remaja menggunakan uji analisis korelatif pearson product moment.

\section{Hasil dan Pembahasan}

Hasil penelitian ini karakteristik responden dalam penelitian ini berdasarkan jenis kelamin, jumlah responden terbanyak adalah berjenis kelamin laki-laki dengan jumlah 30 responden $(66,7 \%)$ sedangkan jumlah responden perempuan berjumlah 15 responden (33,3\%). sebaran pendidikan terakhir responden terbanyak adalah SMA/ Sederajat dengan jumlah 31 responden (68,9\%), kemudian diikuti oleh SMP/ Sederajat dengan jumlah responden 12 responden $(26,7 \%)$, sedangkan jumlah responden SD/ Sederajat berjumlah 2 responden $(4,4 \%)$. nilai distribusi pengetahuan kesehatan reproduksi memiliki nilai minimum 10 , nilai maksimal, 22 , nilai mean 15.16 , nilai median 15 , nilai modus 15 , dan nilai standart deviasi 2,899. nilai distribusi kecemasan memiliki nilai minimum 75 , nilai 
maksimal, 160, nilai mean 105.69, nilai median 100, nilai modus 110, dan nilai standart deviasi 19.589 .

Tabel I. Hubungan antara pengetahuan kesehatan reproduksi dengan kecemasan

\begin{tabular}{cccc}
\hline & $\begin{array}{c}\text { Jumlah } \\
\text { Sampel }\end{array}$ & Sig & $\begin{array}{c}\text { Pearson } \\
\text { Correlation }\end{array}$ \\
\hline Nilai & 45 & .007 & .396 \\
\hline
\end{tabular}

Berdasarkan tabel I bahwa penelitian ini mendapatkan hasil nilai signifikansi .007 nilai tersebut $<0,05$ yang berarti bahwa terdapat hubungan antara pengetahuan kesehatan reproduksi dengan kecemasan. Untuk nilai koefisiensi pearson correlation mendapatkan nilai 0.396 yang berarti bahwa kekuatan hubungan antara pengetahuan kesehatan reproduksi dengan kecemasan memiliki kekuatan hubungan kategori rendah, sehingga hasil dari penelitian ini untuk arah hubungan antara pengetahuan kesehatan reproduksi dengan kecemasan memiliki arah hubungan yang positif, semakin tinggi pengetahuan kesehatan reproduksi maka akan semakin tinggi juga nilai kepercayaan diri yang dimana berarti remaja dalam penelitian ini tidak mengalami kecemasan.

\section{Simpulan}

Kecemasan akan memiliki dampak dalam hubungan sosial ataupun tentang konsep kedirian remaja itu sendiri. Pendapat yang dikemukan oleh Taylor kecemasan merupakan pengalaman subyektif mengenai ketegangan mental yang menggelisahkan sebagai bentuk reaksi umum dan ketidakmampuan menghadapi masalah atau munculnya rasa tidak aman pada individu, dan yang perlu kita sadari adalah bahwa Reaksi emosional/cemas terhadap situasi yang menekan merupakan bagian dari pengalaman manusia sehari-hari (Setiyani et al., 2015).

Pengetahuan kesehatan reproduksi dalam penelitian ini memiliki hubungan yang signifikan terhadap kecemasan, tetapi dari hasil uji kekuatan hubungan memiliki nilai hubungan yang rendah, hal ini berarti bahwa pengetahuan kesehatan reproduksi meskipun berhubungan dengan kecemasan remaja secara umum tetapi ternyata tidak menjadi faktor yang utama dalam mempengaruhi kecemasan tersebut, kecemasan pada remaja bisa diakibatkan oleh beberapa faktor lain yang melingkupi kehidupan remaja (Sarwono, 2011).

Selain faktor lingkungan, faktor individu dalam memahami kesehatan reproduksi adalah hal yang lebih utama, karena dengan berangkat berdasarkan pengetahuan sendiri tentang kesehatan reproduksi maka seorang remaja dalam kasus ini akan lebih mawas diri dan lebih tahu cara harus bersikap dan berperilaku ataupun menangkap dalam citra psikologis nantinya, sehingga kecemasan dapat ditekan (Soetjiningsih, 2010).

\section{Ucapan Terima Kasih}

Kami ucapkan terima kasih kepada Lembaga Penelitian dan Pengabdian Masyarakat (LPPM) STIKES Nasional yang telah membiayai penelitian ini, selanjutnya peneliti berterima kasih kepada remaja karang taruna desa Pandean yang telah dengan senang hati dan terbuka untuk berperan aktif dalam menjalani penelitian ini, kepada kepala desa Pandean yang telah memberikan kesempatan dan dukungan kepada peneliti untuk melakukan penelitian di desa Pandean.

\section{Daftar Pustaka}

Depkes RI. Profil kesehatan Indonesia 2001 Menuju Indonesia sehat 2010. Jakarta: Departemen Kesehatan RI. 2002:40.

Kanari, Nani. 2011. dalam Wardhani, Novia. 2011. Hubungan Pengetabuan Remaja Tentang Perubahan Fisik Pubertas Dengan Tingkat Kecemasan Menghadapi Pubertas Di SMP Negeri 1 Kasiban Tabun 2011. Sekolah Tinggi Ilmu Kesehatan Jenderal Achmad Yani Program Studi Diploma Iii Kebidanan Yogyakarta.

Proverawati dan Misaroh. 2009. Menarche Menstruasi Pertama Penub Makna.Yogyakarta: Nuha Medika.

Sarwono, SW. 2011. Psikologi Remaja. Jakarta: PT Rajagrafindo Persada

Setiyani, Fira Atika. Prasojo, Sigit dan Zuhana, Nina. 2015. Kecemasan Ibu Mengenai Perilaku Seksual di Pekalongan. Jurnal Ilmiah Kesehaan (JIK) Vl VII, No 1 Maret 2015

Soetjiningsih, 2010, Tumbub Kembang Remaja dan Permasalabannya, Sagung Seto, Jakarta.

WHO, 2010. The World Health. Report 2010. 